\title{
Potential COVID-19 Drug from Natural Phenolic Compounds through In Silico Virtual Screening Approach
}

\author{
Thirumalaisamy Rathinavel ${ }^{1}$, Bhuvaneswari Meganathan ${ }^{1}{ }^{(\mathbb{D})}$, Suresh Kumarasamy ${ }^{2, *(\mathbb{D})}$, Subramanian \\ Ammashi $^{3}$ (D) , Selvankumar Thangaswamy ${ }^{4}$ (D), Yuvarajan Ragunathan ${ }^{4}$ (D), Srinivasan Palanisamy ${ }^{4}$ (D) \\ 1 Department of Biotechnology, Sona College of Arts and Science, Salem (Dt.) -636 005, Tamil Nadu, India \\ 2 PG and Research Center in Biotechnology, MGR College, Hosur, Tamilnadu, 635130, India \\ 3 Department of Biochemistry, Rajah Serfoji Government College, Thanjavur (Dt.) -613 005, Tamil Nadu, India \\ 4 Department of Biotechnology, Mahendra Arts and Science College, Namakkal (Dt.) -637 501, Tamil Nadu, India \\ * Correspondence: sureshbioteck@yahoo.com;
}

Received: 5.09.2020; Revised: 4.10.2020; Accepted: 7.10.2020; Published: 13.10.2020

\begin{abstract}
SARS CoV-2 causes a world pandemic disease called COVID-19. In the present study, natural phenol and flavonoid compounds from food sources are used to search for effective drug candidates for treating novel coronavirus 2019. Thirtyfive natural phenolic compounds were taken for our study. Four levels of in silico virtual screening (Drug likeliness, Docking study, ADME, and DFT analysis) was carried out to find effective drug candidate against SAR-CoV-2. 23 Compounds were shortlisted from 35 compounds by preliminary Drug likeliness screening carried out according to five different drug rules. A docking study of 23 compounds against three viral protein targets of SAR-CoV2 reveals four best-docked compounds, such as Quercetin (CID 5280343), Rosmarinic acid (CID 5281792), Hesperidin (CID 72281), and Naringenin (CID 932). Finally, these four phenolic compounds were subjected to final in silico screening steps such as ADME and DFT analysis. These compounds were considered as the best drug candidate for SARS CoV- 2. These four selected phenolic compounds show better binding affinity with SARS-CoV-2 viral protein targets, which also possess excellent physicochemical and pharmacokinetic properties. Moreover, these compounds virtually present in every food substance, so nutritional supplements of these fruits and vegetables with these compounds act as best warriors to combat COVID-19. Further, in vivo analysis is needed to explore the molecular mechanism behind the inhibition of SAR-CoV-2 viral proteins with these compounds.
\end{abstract}

Keywords: COVID-19; Hesperitin; Naringenin; Rosmarinic acid; SARS CoV-2; Quercetin.

(C) 2020 by the authors. This article is an open-access article distributed under the terms and conditions of the Creative Commons Attribution (CC BY) license (https://creativecommons.org/licenses/by/4.0/).

\section{Introduction}

Severe Acute Respiratory Syndrome Corona Virus -2 (SARS CoV-2) emerged from Wuhan city, Hubei Province, China, as an unidentified pneumonia disease in December 2019. Afterward, it is confirmed as a novel coronavirus (nCoV-2019) that causes a world pandemic disease called COVID-19 through international air passengers. Coronavirus is one of the largest families of the virus, SARS CoV-2 belongs to the beta coronavirus type, and it possesses a crown-like spike structure in its surface. It can spread the COVID-19 disease to more than two hundred countries, and last, it lasts more than the past six months. The higher mutation rate of SARS CoV-2 may be the reason behind it that can survive the spread and cause diseases in all races of the human population. There is no proper medication and treatment for COVID-19. 
As of $6^{\text {th }}$ June, COVID-19 counts 6.5 million infected cases with 3 million recovered cases and 0.38 million deaths worldwide [1].

The sequence similarity of SARS-CoV-2 with the Bat coronavirus revealed that $96.2 \%$ resemblance, whereas another study showed that the coronavirus from the pangolin snake shares $99 \%$ sequence similarity with SARS-CoV-2 [2,3]. It proves that SARS CoV-2 may be aroused from natural hosts such as a bat or pangolin snake. The basic reproduction number $\left(\mathrm{R}_{0}\right)$ refers to the average number of secondary infections produced by patients to a susceptible population without intervention [4]. $\mathrm{R}^{0}$ is varied among the different viral strains. The novel coronavirus 2019 possesses $\mathrm{R}^{0}$ value of 2.47-2.86 [5]. Patients with existing other clinical diseases are more susceptible to SARS-CoV-2 because of their poor immune system to combat COVID-19 has a higher risk to recover may leads to death [6]. Therefore one thing that is considered important to combat COVID-19 is boosting the immune system of every individual with food and other natural product supplements [7,8]. Drug candidate from natural origin shows a valuable source for rapid and safe drug discovery for SARS-CoV-2.

Phenolic compounds are uniformly dispersed phytochemicals contained and abundant in any tissue of most plant families around the world, especially in fruits and vegetables that are part of the plant.[9]. Phenolic compounds are classified based on their chemical structures into phenolic acids, flavonoids, tannins, coumarins, lignans, quinones, stilbenes, and curcuminoids. Phenolic compounds are synthesized through the shikimic acid pathway in plants as secondary metabolites are generally involved in plant adaptation to environmental stress conditions. Phenolic and flavonoids compounds are secondary metabolites of the plant that possess an aromatic ring with at least one hydroxyl group [10]. Among the chemically diverse natural therapeutic agents, flavonoid and phenolic compounds were the most promising active compounds against SARS-CoV-2, due to their excellent pharmacokinetic properties [11,12].

Phenolic related compounds have been reported to possess numerous biological activities such as antioxidants, anti-cancer, anti-inflammatory, antibacterial, cardioprotective and immune system promoting activities [13-16]. Several studies have shown that phenol and flavonoids related compounds from medicinal plants increases human health and boost human immune power $[17,18]$. Natural polyphenolic compounds are mainly derived from plant origins. These phenolic and flavonoid class of compounds possess antiviral activities against a number of viruses such as rhinoviruses, hepatitis $\mathrm{C}$ virus, HIV, yellow fever, herpes simplex virus, and influenza viruses [19]. Nowadays, pharmacology companies manufacture potential drug molecules in a short period of time with the aid of most fascinating bioinformatics tools and applications [20]. The present study was focused on the aim of screening potential drug candidates for COVID-19 from phenolic compounds.

\section{Materials and Methods}

\subsection{Compounds selection and preparation for study.}

A list of thirty-five natural phenolic compounds was selected from the previous literature survey and taken for our in silico virtual screening study. 2D structures of phenolic compounds were retrieved from PubChem, a database of chemical molecules (Table 1). 2D SDF file format was submitted to "Online SMILES convertor and Structure file generator" and converted into standard 3D PDB format for further in silico analysis [21]. 


\subsection{Drug likeliness of phenol and flavonoid compounds.}

Drug Likeliness nature of 35 selected natural phenolic compounds was analyzed using the Swiss ADME online server [22]. Drug likeliness of the compounds was examined by the Swiss ADME server based on Violations of five different rules of drug likeliness such as Lipinski, Ghose, Veber, Egan, and Muegge. The screened compounds possessing having zero and single violations of compounds is taken to the next levels of in silico virtual screening. Lipinski rule is based on the values of MLogP, Molecular weight, No of Hydrogen bond acceptors, and donors less than 4.15,500, $10 \& 5$, respectively. Ghose filter based on values of WlogP, Molar Refractivity, Molecular weight, and Number of atoms (-0.4 to 5.6, 40-130, 160480, 20-70, respectively. As per the Verbier rule of drug likeliness, the molecule should have a rotatable bond count and TPSA less than 10 and 140, respectively. Egan rule is based on WLogP and TPSA values less than 5.88 and 131.6, respectively. Muegge Druk likeliness rule is based on molecular weight (200-600), $\mathrm{X} \operatorname{LogP}(-2$ to +5$)$ TPSA (<150) No of rings (<7) No of carbon and hetero atoms is more than $1 \& 1$ whereas No of rotatable bonds, $\mathrm{H}$ bond, and the donor should be less than $15,10 \& 5$ respectively.

\subsection{Viral target protein.}

Corona viral protein targets such as Spike proteins, Main Protease, and RNA dependent DNA polymerase from nCOV-2019 is taken for our in silico docking work. 3D crystal structures of Spike proteins, Main Protease, and RNA dependent DNA polymerase Targets of nCOV-2019-6M3M,6LU7,7M71 respectively, were retrieved from Research Collaboratory of Structural Bioinformatics - Protein Data Bank (www.rcsb.org) using their PDB ID [23].

\subsection{Molecular docking.}

Autodock Vina (version 4) was employed for the present study, and the calculations were carried out by Autodock tools [24]. Totally three viral targets protein from SARS-CoV-2 and 35 phenolic and flavonoid compounds were taken for our study. The grid map for docking of protein binding pocket was calculated using the Auto grid. The grid size for $\mathrm{x}, \mathrm{y}$, and $\mathrm{z}$ points of dimension was set for each viral target protein is as follows; 6M3M -87x66x71, 6LU7$52 \times 67 \times 886 \mathrm{M} 71-79 \times 84 \times 106$. The auto grid was used to set the grid points space $(0.375 \AA)$ for all the viral protein targets. Other parameters of docking such as docking assessment $(\sim 10$ times), population size (150), energy evaluation (maximum number 250,000) generations (maximum number 27,000), rate of mutations (0.02), rate of cross-over (0.8), and other parameters of docking were set to default values using the autotor utility of the auto dock tool. Docking results pose, and the 2D interaction plot of the viral target protein with ligand was analyzed using receptor-ligand interaction options in Discovery Studio v2.5.

\subsection{ADME calculations.}

PreADMET web-based application is used to determine the pharmacokinetic properties of the best docking scored phenolic compounds. PreADMET predicts the various pharmacokinetic parameters associated with ADME behavior of phytocompounds such as absorption, bioavailability, and metabolism profile of the drug candidate. 


\subsection{DFT analysis.}

DFT analysis provides HOMO-LUMO orbital energies of the compound, which will give the values of molecular electrostatic potential (MEP) that indicates the electrophilic and nucleophilic reactive sites of the compounds and the energy gap. The DFT calculations were performed for phenolic phytocompounds and were done using functional B3LYP with 6-3IG** basic set in Gaussian 09. The important parameter, HOMO-LUMO, orbital energies that are used to assess the ionization energy, electron affinity, electronegativity, electronic chemical potential, molecular hardness, softness, and electrophilicity index are calculated to reveal the compounds stability and chemical reactivity.

\section{Results and Discussion}

\subsection{Drug likeliness calculation.}

Drug likeliness calculations for 35 natural phenolic and flavonoids compounds were done using the Swiss ADME server, and their results were presented in Table 1. Five different rules, such as For drug likeliness measurement of natural phenolic compounds Lipinski, Ghose, Veber, Egan, and Muegge, are considered. For the next step of silico sampling, out of 35 compounds, 15 compounds with zero infringement against five laws, 5 compounds with a single infringement in a single law, 3 compounds with a single infringement in two rules were picked. Selected 23 compounds from drug likeliness calculations are subjected to docking study against three different viral protein targets of SARS- CoV-2.

Table 1. Drug likeliness calculation for selected phenolic and flavonoids compounds against SARS CoV-2.

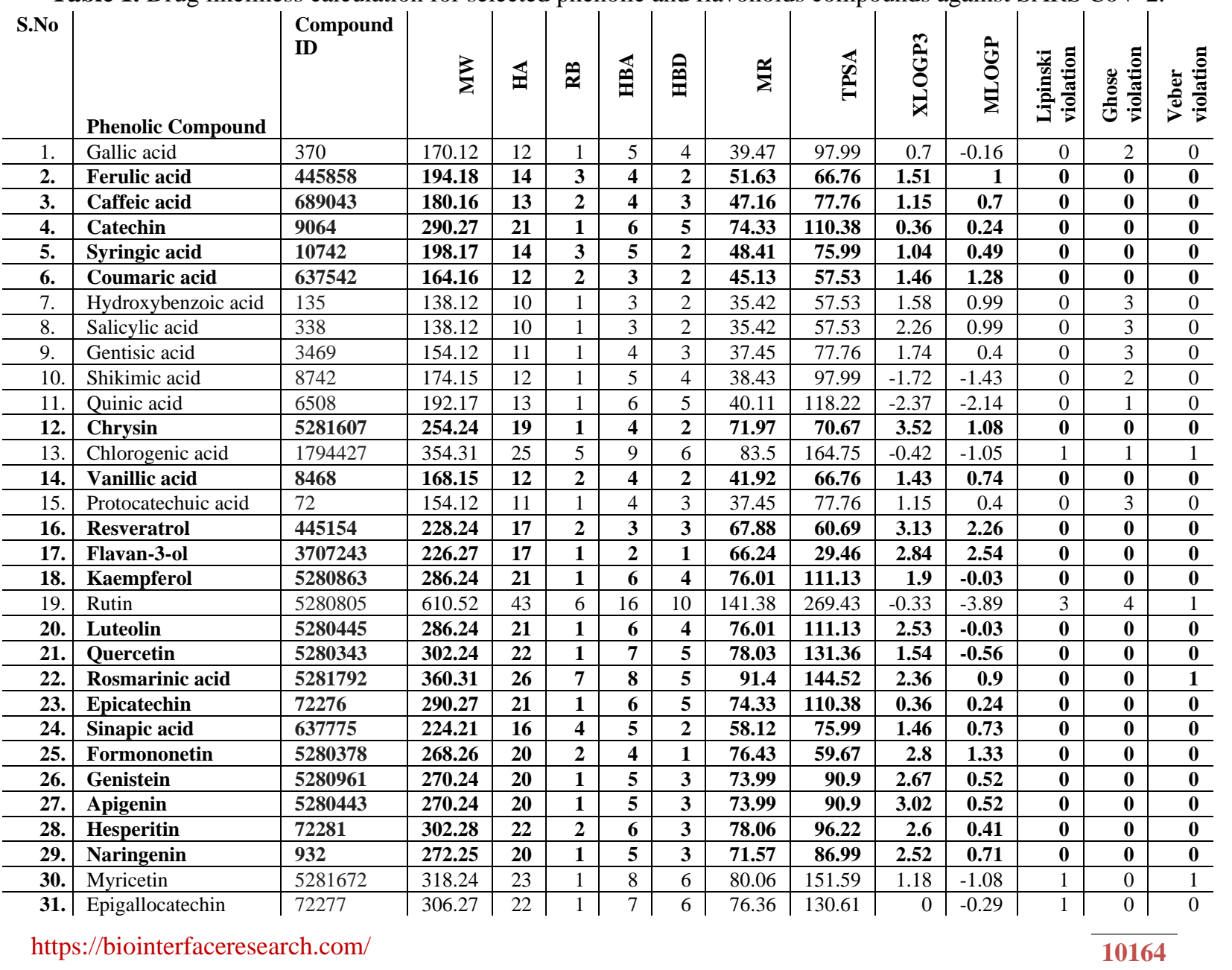




\begin{tabular}{|c|c|c|c|c|c|c|c|c|c|c|c|c|c|c|}
\hline S.No & Phenolic Compound & $\begin{array}{l}\text { Compound } \\
\text { ID }\end{array}$ & $\sum$ & 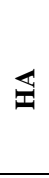 & $\underline{\simeq}$ & 苗 & 茴 & 㤐 & 岕 & 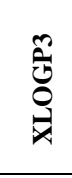 & 灾 & 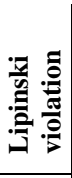 & 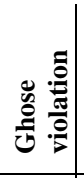 & 㐫 \\
\hline 32. & Gallocatechin & 65084 & 306.27 & 22 & 1 & 7 & 6 & 76.36 & 130.61 & 0 & -0.29 & 1 & 0 & 0 \\
\hline 33. & Theaflavin & 135403798 & 564.49 & 41 & 2 & 12 & 9 & 143.98 & 217.6 & 2.38 & -0.79 & 3 & 2 & 1 \\
\hline 34. & Thearubigin & 100945367 & 902.72 & 65 & 12 & 22 & 13 & 216.99 & 385.26 & 2.88 & -1.74 & 3 & 3 & 2 \\
\hline 35. & Eriodictyol & 440735 & 288.25 & 21 & 1 & 6 & 4 & 73.59 & 107.22 & 2.02 & 0.16 & $\mathbf{0}$ & $\mathbf{0}$ & $\mathbf{0}$ \\
\hline
\end{tabular}

The calculation of the physicochemical properties of the many molecules is much needed to determine its drugability nature. $90 \%$ of compounds with zero violations of the Lipinski rule have reached phase 2 clinical status; however, it doesn't guarantee the molecules meet drug-like property. Drug distribution and its excretion mainly depend on the topological polar surface (TPSA), so the compounds with TPSA value of 140 or less and ten rotatable bonds is considered as a potential drug candidate. A recent research report reveals that natural products and its drug likeliness screening has shown that natural compounds following Lipinski and Veber's rule can act as drug candidates against SARS-CoV-2 [25].

\subsection{Molecular docking analysis.}

Docking results for 23 compounds against three different viral protein targets of SARSCoV-2 is presented in Table 2. Natural phenolic and flavonoid compounds exhibited binding affinity in the range of -5.5 to $9.0 \mathrm{Kcal} / \mathrm{mol}$ against three different viral target proteins. The top two docks scored compounds from each viral target proteins, and its interactions were presented in Table 3.Compound quercetin (CID 5280343) possesses the highest binding affinity of $-7.7 \mathrm{Kcal} / \mathrm{mol}$ with SARS-CoV-2 RNA dependent RNA polymerase (6M71), and the amino acid residues of 6M71 show one hydrogen bonding Glu320 and three alkyl interactions Val315, Pro461, Pro677 with the phenolic ligand Quercetin. Hesperitin (CID 72281 ) shows a docking score of $-7.6 \mathrm{Kcal} / \mathrm{mol}$ with $6 \mathrm{M} 71$ viral protein target having two alkyl (Val71, Thr123) and four hydrogen-bonding interactions (Arg33, Ala34, Tyr69, Thr120) between them.

SARS-CoV-2 Main protease (MPro) PDB ID 6LU7 highest binding affinity $8.0 \mathrm{Kcal} / \mathrm{mol}$ ) with the ligand Rosmainic acid (CID 52781792). Mpro viral target protein residues show two alkyl Val104, Phe294, and five hydrogen bonding Lys102, Gln110, Thr111, Asp153, Ser158, interactions of with ligand Rosmarinic acid. Another phenolic compound Naringenin (CID 932), possess a docking score of $-7.9 \mathrm{Kcal} / \mathrm{mol}$ against MPro viral protein target, and it showed more interactions of three alkyl His41, Met49, Cys145, and six hydrogen bonding Tyr54, Leu141, Gly143, Ser144, His164, Glu166 amino acid residues of MPro viral target proteins with ligand naringenin.

The crystal structure of SARS-CoV-2 nucleocapsid protein with the N- terminal RNA binding domain shows a better binding affinity with screened natural phenolic compounds. Hesperidin (CID 72281) and Quercetin (CID 5280343) shows the top two docking scores of -9.0 and $-8.8 \mathrm{Kcal} / \mathrm{mol}$ with nucleocapsid viral protein target (PDB ID 6M3M) respectively. Hesperidin shows four hydrogen-bonding interactions (Leu160, Gln161, Leu162, Gly165), whereas Quercetin shows two alkyls (Thr136, Pro163) and four hydrogen bonding (Leu162, Pro163, Gly165, Thr166) interactions with nucleocapsid protein viral target (Figure 1-6 a \& b). 
Table 2. Docking score of phenolic compounds against protein targets of SARS CoV- 2.

\begin{tabular}{c|l|l|l|l|l} 
S.No & Phenolic Compound & \multirow{2}{*}{ Compound ID } & nCoV-2019 Protein Targets \\
\cline { 4 - 6 } & & & 6M3M & 6LU7 & 6M71 \\
\hline 1. & Ferulic acid & 445858 & -6.3 & -5.9 & -5.5 \\
\hline 2. & Caffeic acid & 689043 & -6.5 & -6.0 & -6.2 \\
\hline 3. & Catechin & 9064 & -8.5 & -7.1 & -6.9 \\
\hline 4. & Syringic acid & 10742 & -6.0 & -5.5 & -5.5 \\
\hline 5. & Coumaric acid & 637542 & -6.1 & -5.9 & -5.6 \\
\hline 6. & Chrysin & 5281607 & -8.5 & -7.2 & -7.2 \\
\hline 7. & Vanillic acid & 8468 & -5.7 & -5.4 & -5.8 \\
\hline 8. & Resveratrol & 445154 & -7.3 & -6.6 & -7.1 \\
\hline 9. & Flavan-3-ol & 3707243 & -7.7 & -6.7 & -6.8 \\
\hline 10. & Kaempferol & 5280863 & -8.6 & -7.6 & -7.1 \\
\hline 11. & Luteolin & 5280445 & -8.7 & -7.4 & -7.4 \\
\hline 12. & Quercetin & $\mathbf{5 2 8 0 3 4 3}$ & $\mathbf{- 8 . 8}$ & -7.4 & $-\mathbf{7 . 7}$ \\
\hline 13. & Rosmarinic acid & $\mathbf{5 2 8 1 7 9 2}$ & -8.5 & $\mathbf{- 8 . 0}$ & -7.3 \\
\hline 14. & Epicatechin & 72276 & -8.6 & -7.1 & -7.5 \\
\hline 15. & Sinapic acid & 637775 & -7.1 & -6.1 & -5.7 \\
\hline 16. & Formononetin & 5280378 & -8.4 & -7.1 & -6.9 \\
\hline 17. & Genistein & 5280961 & -8.2 & -7.5 & -7.5 \\
\hline 18. & Apigenin & 5280443 & -8.4 & -7.8 & -7.4 \\
\hline 19. & Hesperitin & $\mathbf{7 2 2 8 1}$ & $\mathbf{- 9 . 0}$ & -7.3 & $-\mathbf{7 . 6}$ \\
\hline 20. & Naringenin & $\mathbf{9 3 2}$ & -8.5 & $-\mathbf{7 . 9}$ & -7.2 \\
\hline 21. & Epigallocatechin & 72277 & -8.7 & -7.4 & -7.1 \\
\hline 22. & Gallocatechin & 65084 & -8.5 & -7.1 & -6.9 \\
\hline 23. & Eriodictyol & 440735 & -8.5 & -7.4 & -7.4
\end{tabular}

Natural compound with therapeutic activity against viral protein target is considered as an important antiviral compound class due to its potential capacity to block viral infection at an early stage. Emodin and its related anthraquinone derivatives show better blockage of ACEII and spike protein interaction; this will leads to the synthesis of anthraquinone based derivatives, namely SSAA09E3, with better pharmacokinetic property [26,27]. Investigation of Isatis indigotica derived alkaloids and phenolic compounds with Mpro in vitro inhibitory action and its potent semi-synthetic isatin derivative developed with Mpro inhibition at a nanomolar concentration $(0.37 \mathrm{mM})[28,29]$.

Epigallocatechin gallate and gallocatechin gallate showed excellent Mpro inhibitory activity (IC50 73 and 47mM, respectively) [30]. Ul Qamar reported it screened 32 thousand compounds from natural products against 3CLpro shows the most promising action on viral target [31]. Some common flavonoids such as Quercetin, apigenin, and luteolin possess better in vitro inhibitory activity, and its finding suggested that larger polyhydroxylated compounds are more preferable to develop a potent inhibitor for viral protein targets [32].
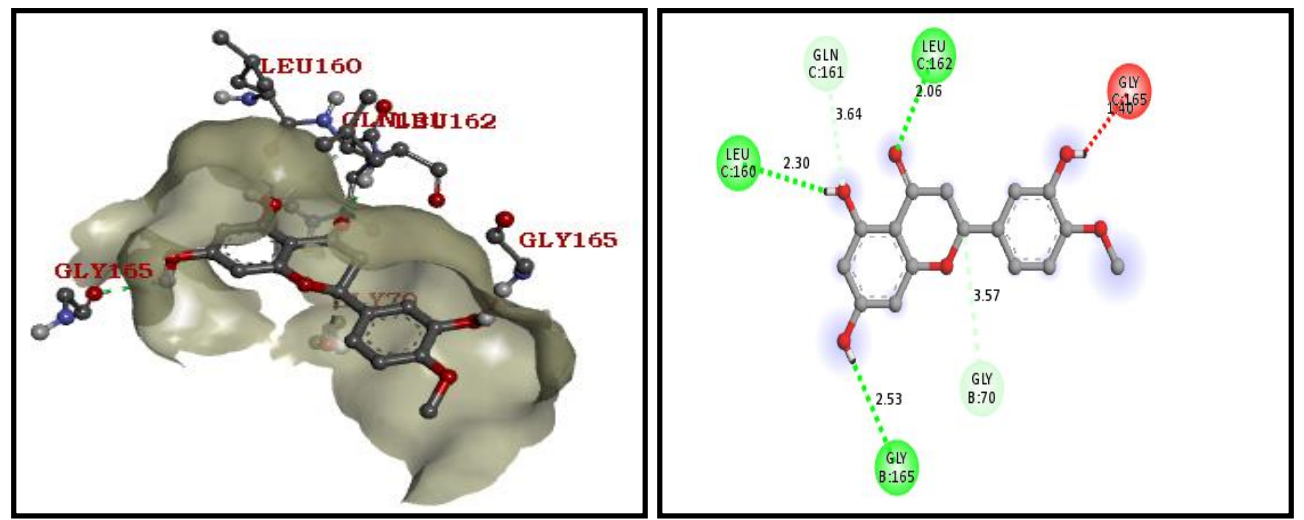

Figure 1. Docking pose and interaction plot for Hesperitin (CID_72281) against 6M3M (-9.0 Kcal/mol). 

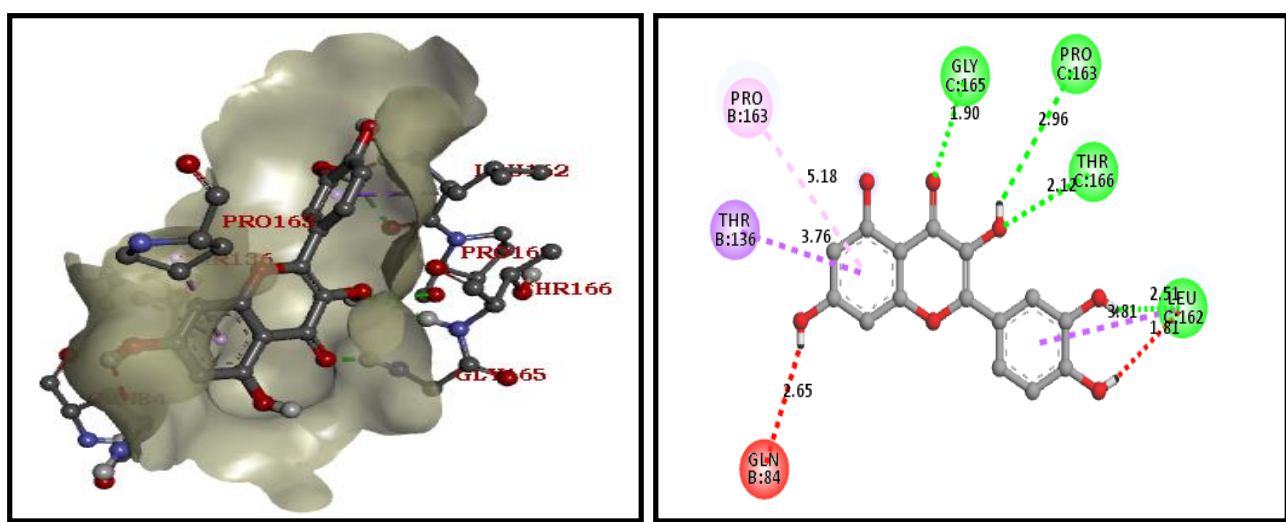

Figure 2. Docking pose and interaction plot for Quercetin (CID_5280343) against 6M3M (-8.8 Kcal/mol).
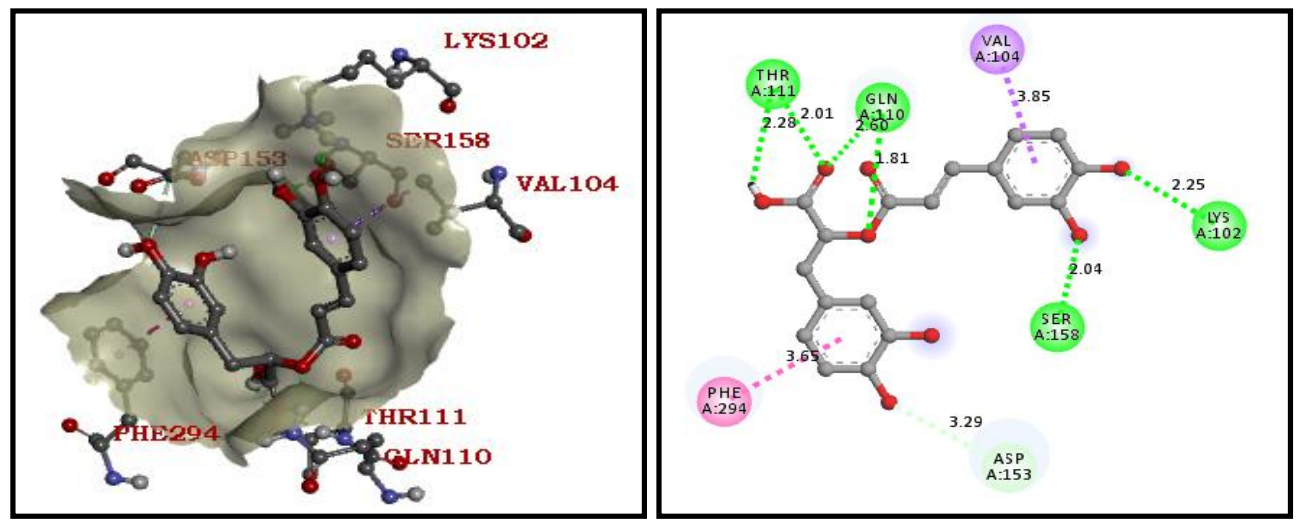

Figure 3. Docking pose and interaction plot for Rosmarinic acid (CID_5281792) against 6LU7 (-8.0 Kcal/mol).
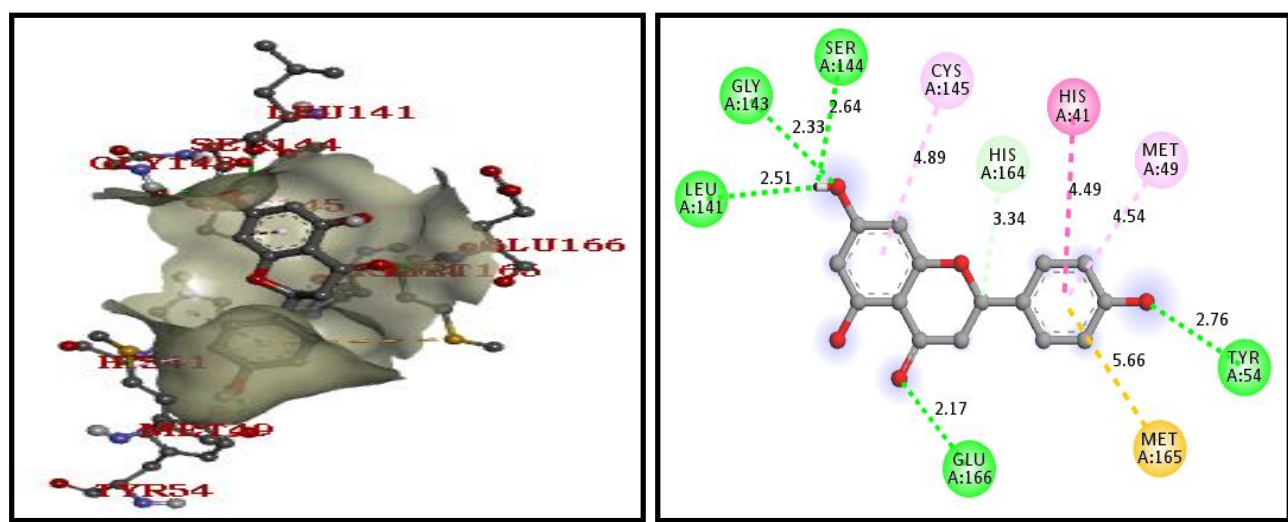

Figure 4. Docking pose and interaction plot for Naringenin (CID_932) against 6LU7 (-7.9 Kcal/mol).
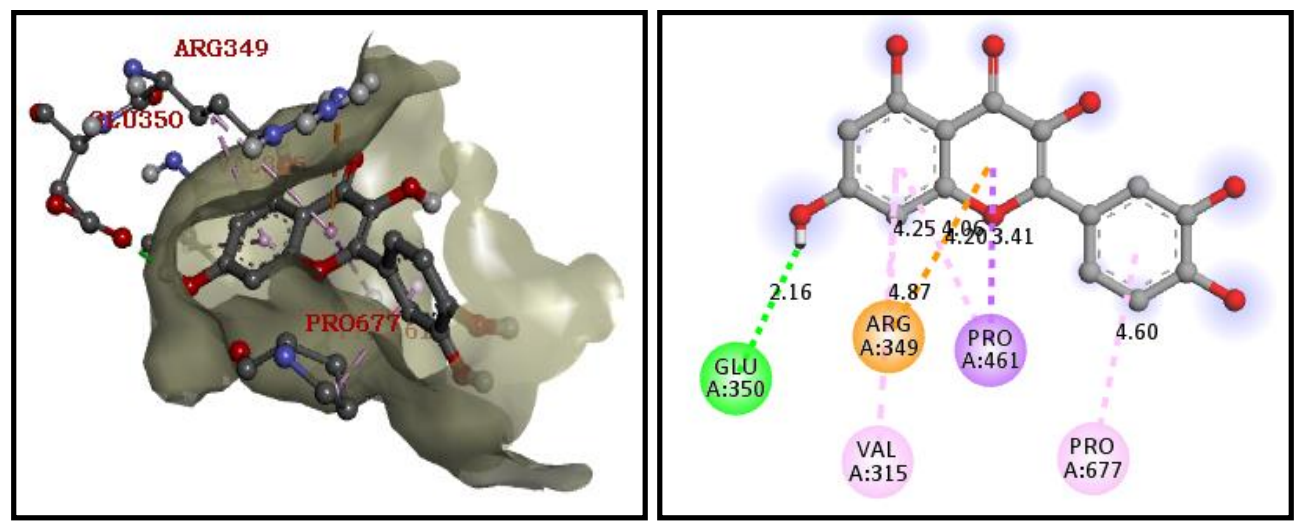

Figure 5. Docking pose and interaction plot for Quercetin (CID_5280343) against 6M71 (-7.7 Kcal/mol). 

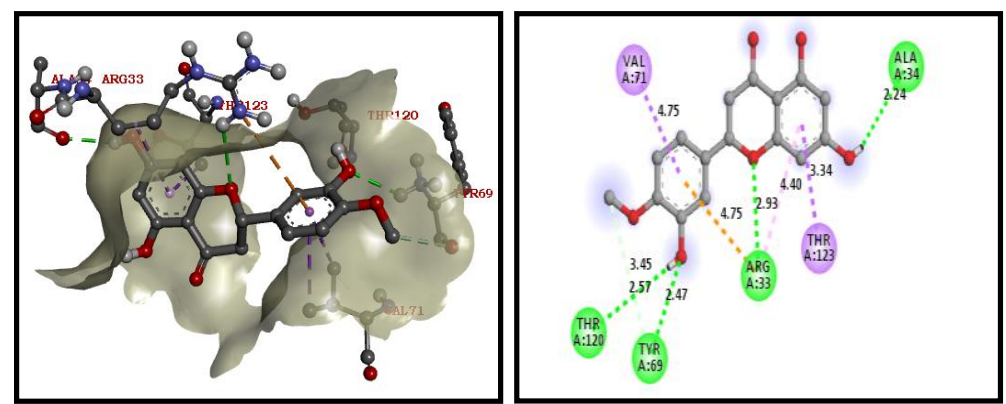

Figure 6. Docking pose and interaction plot for Hesperitin (CID_77281) against 6M71 (-7.6 Kcal/mol).

Table 3. Top two docking scored compounds against three SARS CoV-2 viral target proteins and its interaction.

\begin{tabular}{|c|c|c|c|c|c|}
\hline S.No & $\begin{array}{l}\text { Docking } \\
\text { Complex } \\
\text { (Target-Ligand) }\end{array}$ & $\begin{array}{l}\text { Docking } \\
\text { Score } \\
\text { (-kcal/mol) }\end{array}$ & $\begin{array}{l}\text { No of } \\
\text { Alkyl } \\
\text { Bonds } \\
\end{array}$ & $\begin{array}{l}\text { No of } \\
\text { H } \\
\text { Bonds } \\
\end{array}$ & Residues Involved in Alkyl Interactions and Hydrogen Bonding \\
\hline 1. & $6 \mathrm{M} 3 \mathrm{M}-72281$ & -9.0 & - & 4 & Leu160*,Gln161*,Leu162*,Gly165* \\
\hline 2. & 6M3M-5280343 & -8.8 & 2 & 4 & Thr136,Leu162*,Pro163\#,Gly165*,Thr166* \\
\hline 3. & 6LU7-5281792 & -8.0 & 2 & 5 & Lys102*,Val104,Gln110*,Thr111*,Asp153*,Ser158*,Phe294 \\
\hline 4. & 6LU7-932 & -7.9 & 3 & 6 & His41,Met49,Tyr54*,Leu141*,Gly143*,Ser144*,Cys145,His164*,Glu166* \\
\hline 5. & $6 \mathrm{M} 71-5280343$ & -7.7 & 3 & 1 & Val315,Glu320*,Pro461,Pro677 \\
\hline \multirow[t]{2}{*}{6.} & 6M71-72281 & -7.6 & 2 & 4 & Arg33*,Ala34*,Tyr69*,Val71,Thr120*,Thr123 \\
\hline & \multicolumn{5}{|c|}{ Legend: * symbol denotes amino acid residues with $\mathrm{H}$ bonding } \\
\hline
\end{tabular}

Similar in silico docking study reported that standard antiviral drugs exhibit binding affinity in the range of -6.9 to- $9.3 \mathrm{Kcal} / \mathrm{mol}$ against RNA dependent RNA polymerase (RdRp) viral protein target. In that reported study shown that RdRp viral protein exhibit binding affinity of $-7.8,-6.9,-9.3 \mathrm{Kcal} / \mathrm{mol}$ with ribavirin, tenofovir, and setrobuvir, respectively [33].

\subsection{ADME calculations.}

The best four docked compounds, such as Quercetin, rosmarinic aid, hesperidin, and naringenin against three viral protein targets, are taken for ADME screening, and their results were presented in Table 4. All four screened compounds show good pharmacokinetic properties such as Human intestinal absorption (HIA) in the range of 62.48 to $87.31 \%$, colon cell absorption in the range of 3.41 to $20.72 \mathrm{~nm} / \mathrm{sec}$. Buffer and pure water solubility value of the compounds in the range of 64.47 to 63626 and $90.92-347.24 \mathrm{mg} / \mathrm{l}$, respectively. Similarly, four shortlisted compounds exhibit excellent plasma protein binding $\%$ and blood-brain barrier penetration values in the range of 86-100\% and 0.1044-0.5969, respectively. Rosmarinic acid shows good human colon cell permeability Caco-2 and skin permeability values (20.7246 $\mathrm{nm} / \mathrm{sec} \&-3.3275$ respectively) and better bioavailability parameters such as buffer and water solubility 63.6 and $0.35 \mathrm{~g} / \mathrm{ml}$ respectively. Compound naringenin shows good human intestinal absorption and MDCK cell permeabilities $87.31 \%$ and $44.65 \mathrm{~nm} / \mathrm{sec}$, and it also possesses excellent distribution parameters such as plasma protein binding and blood-brain barrier penetration values such as $100 \%$ and 0.5969 , respectively. Cytochrome 450 isoenzymes from the kidney play an important role in the detoxification mechanism necessary for clearance of every drug molecules from the body is screened against four shortlisted compounds. Rosmarinic acid (CID 52781792) had shown no inhibition against all isoforms of cytochromes enzymes involved in the xenobiotic mechanism. Compounds hesperidin (CID 72281) and naringenin (CID 932) shows inhibition against CYP 1A2 and 3A4; additionally, Quercetin (CID 5280343) shows inhibition against CYP2D6 isoenzyme forms of cytochrome responsible for drug clearance. 
Table 4. ADME properties of final shortlisted phenolic compounds against SARS CoV-2.

\begin{tabular}{|c|c|c|c|c|c|c|}
\hline \multirow[t]{2}{*}{ S.No } & \multicolumn{2}{|c|}{ Pharmacokinetic Properties } & \multicolumn{4}{|c|}{ Phenolic Compounds } \\
\hline & & & \multirow{2}{*}{$\begin{array}{l}\text { Quercetin } \\
63.48522 \\
\end{array}$} & \multirow{2}{*}{$\begin{array}{l}\begin{array}{l}\text { Rosmarinic } \\
\text { acid }\end{array} \\
62.48758\end{array}$} & \multirow{2}{*}{$\begin{array}{l}\text { Hesperitin } \\
87.19291 \\
\end{array}$} & \multirow{2}{*}{$\begin{array}{l}\text { Naringenin } \\
87.31807\end{array}$} \\
\hline \multirow[t]{4}{*}{1.} & \multirow[t]{4}{*}{ ABSORPTION } & $\begin{array}{l}\text { Human Intestinal } \\
\text { Absorption (HIA \%) }\end{array}$ & & & & \\
\hline & & $\begin{array}{lr}\text { Caco-2 } & \text { Cell } \\
\text { Permeability }(\mathrm{nm} / \mathrm{sec})\end{array}$ & 3.4129 & 20.7246 & 7.00371 & 10.5211 \\
\hline & & $\begin{array}{lr}\text { MDCK } & \text { Cell } \\
\text { Permeability }(\mathrm{nm} / \mathrm{sec})\end{array}$ & 13.3528 & 0.20263 & 24.4257 & 44.6354 \\
\hline & & $\begin{array}{l}\text { Skin Permeability } \\
(\log \mathrm{Kp}, \mathrm{cm} / \text { hour })\end{array}$ & -4.43341 & -3.32759 & -4.18756 & -4.18021 \\
\hline \multirow[t]{2}{*}{2.} & \multirow[t]{2}{*}{ BIOAVAILABILITY } & $\begin{array}{l}\text { Buffer } \\
(\mathrm{mg} / \mathrm{l})\end{array} \quad$ Solubility & 64.4795 & 63626.5 & 222.195 & 191.955 \\
\hline & & $\begin{array}{l}\text { Pure Water Solubility } \\
(\mathrm{mg} / \mathrm{l})\end{array}$ & 96.4388 & 347.247 & 90.9293 & 251.402 \\
\hline \multirow[t]{2}{*}{3.} & \multirow[t]{2}{*}{ DISTRIBUTION } & $\begin{array}{ll}\text { Plasma } & \text { Protein } \\
\text { Binding }(\%) & \\
\end{array}$ & 93.2361 & 86.24209 & 96.79283 & 100 \\
\hline & & $\begin{array}{l}\text { Blood Brain Barrier } \\
\text { Penetration }\end{array}$ & 0.172765 & 0.104434 & 0.222751 & 0.59697 \\
\hline \multirow[t]{5}{*}{4.} & \multirow[t]{5}{*}{ METABOLISM } & CYP_1A2 Inhibitor & Yes & No & Yes & Yes \\
\hline & & CYP_2C19_inhibitior & No & No & No & No \\
\hline & & CYP_2C9_inhibitior & No & No & No & No \\
\hline & & CYP_2D6_inhibitior & Yes & No & No & No \\
\hline & & CYP_3A4_inhibitior & Yes & No & Yes & Yes \\
\hline
\end{tabular}

Legend: High scored compound for each ADME parameter is in bold letter

The pharmacokinetic analysis provides a better correlation of time course of drug and their metabolic effect in the human body. It measures and quantifies the absorption, distribution, metabolism, and excretion of the drug inside the human body [34]. Optimal parameters of these pharmacokinetic properties are needed to design the most promising drug to treat a particular disease [35].

\subsection{DFT calculation.}

Results for DFT analysis of four shortlisted phenolic compounds were presented in Table 5, and their Homo-Lumo orbital energies were presented in Figure 6. Among screened compounds, Quercetin shown less energy gap -0.1531 with less hardness -0.0765 and more softness 13.0701, proves the highest binding affinity of the compound against viral protein targets.

Table 5. DFT Calculation for final shortlisted Phenolic compounds against SARS CoV-2.

\begin{tabular}{|c|c|c|c|c|c|c|c|c|c|c|}
\hline $\begin{array}{l}\text { Phenolic } \\
\text { Compoun } \\
\text { d }\end{array}$ & $\begin{array}{l}\text { Compoun } \\
\text { d ID }\end{array}$ & $\begin{array}{l}\text { HOM } \\
\text { O }\end{array}$ & $\begin{array}{l}\text { LUM } \\
\text { O }\end{array}$ & $\begin{array}{l}\text { Energ } \\
\text { y Gap }\end{array}$ & $\begin{array}{l}\text { Ionizatio } \\
\text { n } \\
\text { potential } \\
\text { (IE) } \\
\text { (eV) }\end{array}$ & $\begin{array}{l}\text { Electro } \\
\text { n } \\
\text { affinity } \\
\text { (EA) } \\
(\mathrm{eV})\end{array}$ & $\begin{array}{l}\text { Electro } \\
\text { negativit } \\
\mathbf{y} \\
(\chi) \\
(\mathrm{eV})\end{array}$ & $\begin{array}{l}\text { Electro } \\
\text { chemica } \\
\text { I } \\
\text { potentia } \\
\text { I }(\mu) \\
(\mathrm{eV})\end{array}$ & $\begin{array}{l}\text { Hardnes } \\
\mathbf{s} \\
(\eta) \\
(\mathbf{e V})\end{array}$ & $\begin{array}{l}\text { Softness } \\
(\sigma) \\
(\mathrm{eV})\end{array}$ \\
\hline Quercetin & 5280343 & -0.2064 & $\begin{array}{l}- \\
0.0533\end{array}$ & $\begin{array}{l}- \\
0.1531\end{array}$ & 0.2064 & 0.0533 & 0.1298 & -0.1298 & $\begin{array}{l}-0.0765 \\
\end{array}$ & $\begin{array}{l}13.0701 \\
8\end{array}$ \\
\hline $\begin{array}{l}\text { Rosmarini } \\
\text { c acid }\end{array}$ & 5281792 & -0.2257 & $\begin{array}{l}- \\
0.0637\end{array}$ & $\begin{array}{l} \\
0.1619\end{array}$ & 0.2257 & 0.0637 & 0.1447 & -0.1447 & $\begin{array}{l}-0.0809 \\
\end{array}$ & 12.3609 \\
\hline Hesperitin & 72281 & -0.2152 & $\begin{array}{l}\overline{0} .0449 \\
\end{array}$ & $\overline{0}-1703$ & 0.2152 & 0.0449 & 0.1300 & -0.1300 & -0.0851 & 11.7508 \\
\hline Nan & 932 & -0.2219 & $-\overline{0} 0460$ & $-\overline{0.1758}$ & 0.2219 & 0.0460 & 0.1339 & -0.1339 & -0.0879 & 11.3765 \\
\hline
\end{tabular}

Similarly, Rosmarinic acid and Hesperitin show less energy gap (-0.1619 \& -0.1703), and more softness (12.3609 \& 11.7508), respectively, occupies the next two positions in DFT analysis ranking next to Quercetin (Figure 7). Thus the in silico screening of DFT calculations 
performed here is taking better evidence for the highest binding affinity and highest docking score of theses phenolic ligands with SARS CoV-2 protein targets.
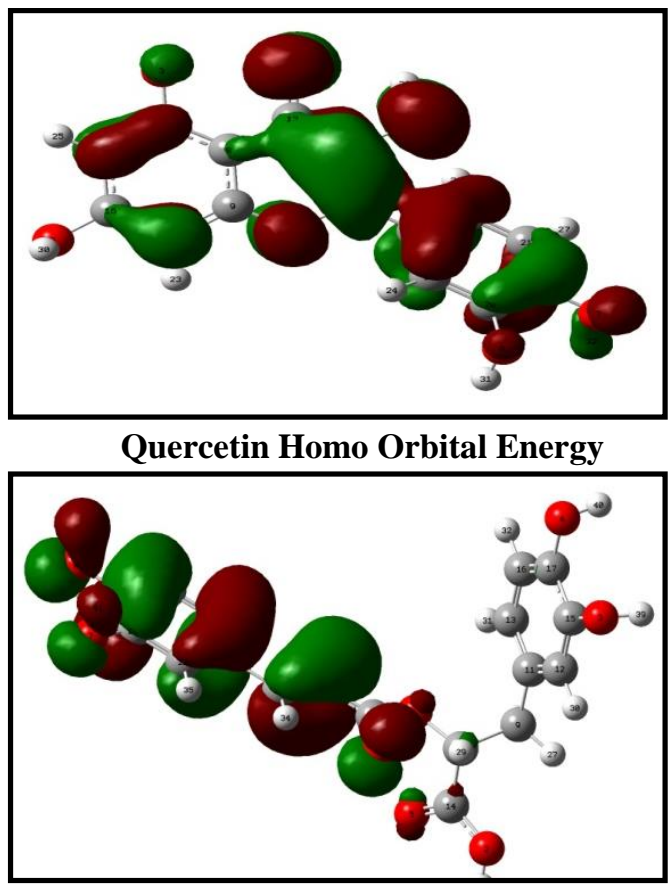

Rosmarinic acid Homo Orbital Energy
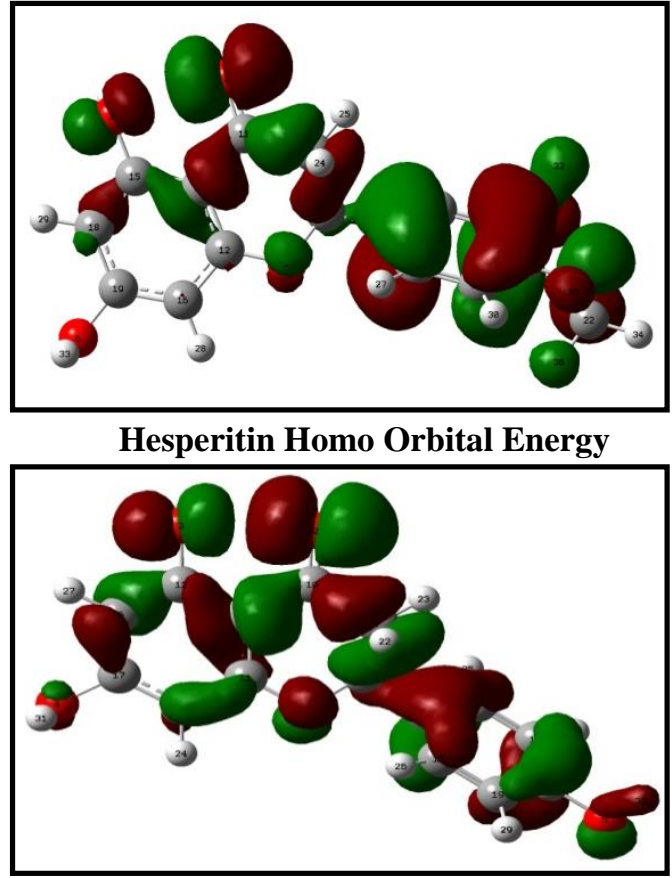

Naringenin Homo Orbital Energy

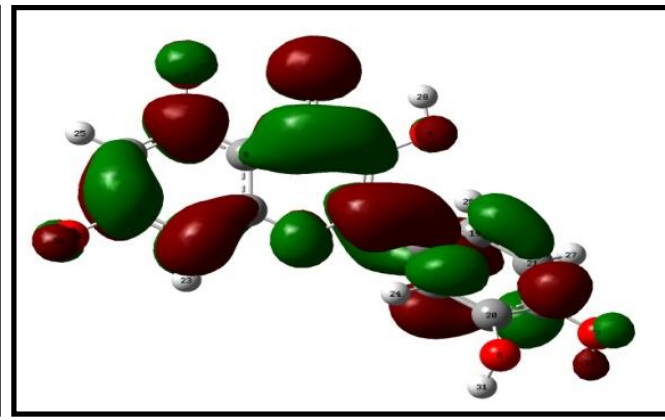

Quercetin Lumo Orbital Energy

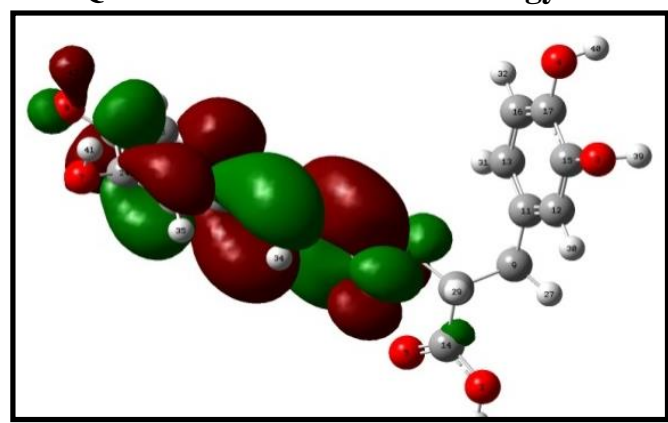

Rosmarinic acid Lumo Orbital Energy

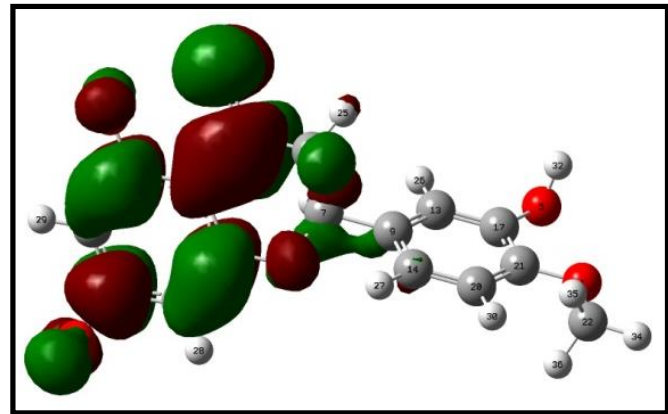

Hesperitin Lumo Orbital Energy

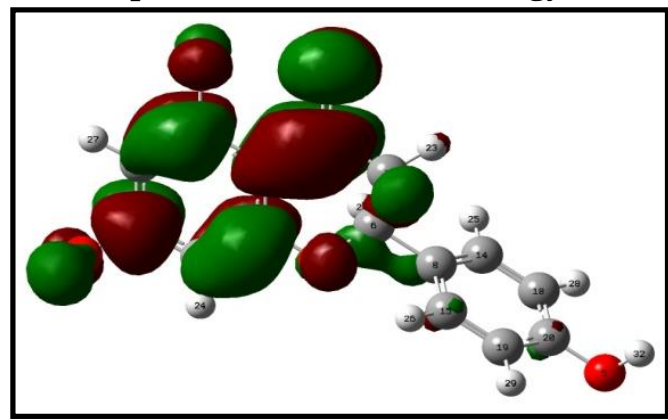

Naringenin Lumo Orbital Energy

Figure 7. DFT study of Four Shortlisted Phenolic compounds against SARS-CoV-2.

Similarly, our previous report phytocompound 6-gingerol $(-0.20606 \mathrm{eV}, 0.10303 \mathrm{eV}$, and $9.3187 \mathrm{eV}$ ) showed more stability and biological activity as it shows less energy gap, low hardness, and more softness [36].

\section{Conclusions}

The present study supported that three phenolic compounds, such as Quercetin, Rosmrinic acid, Hesperitin, show good binding affinity with SARS-CoV-2 viral protein targets. It possesses an excellent physicochemical and pharmacokinetic property, which may best suit 
to treat COVID-19 using these phenolic drug candidates. Moreover, it is very useful in COVID19 treatment practices, and it could act as nutritional supplements of phenolic plant sources that may promote the immune system of the body to combat COVID-19. Further, in vivo screening of these drug candidates will explore the molecular mechanism of its action against SARS-CoV-2 viral protein targets.

\section{Funding}

This research received no external funding.

\section{Acknowledgments}

The authors would like to thank the Department of Biotechnology, Sona College of Arts and Science, Salem (Dt.) -636 005, Tamil Nadu, India, for their technical support.

\section{Conflicts of Interest}

The authors declare no conflict of interest.

\section{References}

1. Worldometer is a provider of global COVID-19 statistics for a wide audience of caring people around the world. https://www.worldometers.info/coronavirus/

2. Zhou, P.; Yang, X.-L.; Wang, X.-G.; Hu, B.; Zhang, L.; Zhang, W.; Si, H.-R.; Zhu, Y.; Li, B.; Huang, C.L.; Chen, H.-D.; Chen, J.; Luo, Y.; Guo, H.; Jiang, R.-D.; Liu, M.-Q.; Chen, Y.; Shen, X.-R.; Wang, X.; Zheng, X.-S.; Zhao, K.; Chen, Q.-J.; Deng, F.; Liu, L.-L.; Yan, B.; Zhan, F.-X.; Wang, Y.-Y.; Xiao, G.-F.; Shi, Z.-L. A pneumonia outbreak associated with a new coronavirus of probable bat origin. Nature 2020, 579, 270-273, https://doi.org/10.1038/s41586-020-2012-7.

3. Xu, X.; Chen, P.; Wang, J.; Feng, J.; Zhou, H.; Li, X.; Zhong, W.; Hao, P. Evolution of the novel coronavirus from the ongoing Wuhan outbreak and modeling of its spike protein for risk of human transmission. Science China Life Sciences 2020, 63, 457-460, https://doi.org/10.1007/s11427-020-1637-5.

4. Remais, J. Modelling environmentally-mediated infectious diseases of humans: transmission dynamics of schistosomiasis in China. Advances in Experimental Medicine and Biology 2010, 673, 79-98, https://doi.org/10.1007/978-1-4419-6064-1_6.

5. Wu, J.T.; Leung, K.; Leung, G.M. Nowcasting and forecasting the potential domestic and international spread of the 2019-nCoV outbreak originating in Wuhan, China: a modelling study. The Lancet 2020, 395, 689-697, https://doi.org/10.1016/S0140-6736(20)30260-9.

6. $\quad$ Liang, W.; Guan, W.; Chen, R.; Wang, W.; Li, J.; Xu, K.; Li, C.; Ai, Q.; Lu, W.; Liang, H.; Li, S.; He, J. Cancer patients in SARS-CoV-2 infection: a nationwide analysis in China. The Lancet Oncology 2020, 21, 335-337, https://doi.org/10.1016/S1470-2045(20)30096-6.

7. High, K.P. Nutritional strategies to boost immunity and prevent infection in elderly individuals. Clinical Infectious Diseases 2001, 33,1892-1900, https://doi.org/10.1086/324509.

8. Simpson, R.J.; Kunz, H.; Agha, N.; Graff, R. Exercise and the Regulation of Immune Functions. Progress in Molecular Biology and Translational Science 2015, 135, 355-80, https://doi.org/10.1016/bs.pmbts.2015.08.001.

9. Agati, G.; Azzarello, E.; Pollastri, S.; Tattini, M. Flavonoids as antioxidants in plants: Location and functional significance. Plant Science 2012, 196, 67-76, https://doi.org/10.1016/j.plantsci.2012.07.014.

10. Gan, R.-Y.; Chan, C.-L.; Yang, Q.-Q.; Li, H.-B.; Zhang, D.; Ge, Y.-Y.; Gunaratne, A.; Ge, J.; Corke, H. 9 Bioactive compounds and beneficial functions of sprouted grains. In: Sprouted Grains. Feng, H.; Nemzer, B.; DeVries, J.W. Eds. AACC International Press: 2019; pp, 191-246, https://doi.org/10.1016/B978-0-12811525-1.00009-9.

11. Islam, M.T.; Sarkar, C.; El-Kersh, D.M.; Jamaddar, S.; Uddin, S.J.; Shilpi, J.A.; Mubarak, M.S. Natural products and their derivatives against coronavirus: A review of the non-clinical and pre-clinical data. Phytotherapy Research 2020, 1-22, https://doi.org/10.1002/ptr.6700.

12. Sayed, A.M.; Khattab, A.R.; AboulMagd, A.M.; Hassan, H.M.; Rateb, M.E.; Zaid, H.; Abdelmohsen, U.R. Nature as a treasure trove of potential anti-SARS-CoV drug leads: a structural/mechanistic rationale. RSC Advances 2020, 10, 19790-19802, https://doi.org/10.1039/D0RA04199H.

13. Chen, X.; Dang, T.-T.T.; Facchini, P.J. Noscapine comes of age. Phytochemistry 2015, 111, 7-13, https://doi.org/10.1016/j.phytochem.2014.09.008. 
14. Działo, M.; Mierziak, J.; Korzun, U.; Preisner, M.; Szopa, J.; Kulma, A. The Potential of Plant Phenolics in Prevention and Therapy of Skin Disorders. International Journal of Molecular Sciences 2016, 17, https://doi.org/10.3390/ijms17020160.

15. Andreu, L.; Nuncio-Jauregui, N.; Carbonell-Barrachina, A.A.; Legua, P.; Hernandez, F. Antioxidant properties and chemical characterization of Spanish Opuntia ficus-indica Mill. cladodes and fruits. Journal of the Science of Food and Agriculture 2018, 98,1566-1573, https://doi.org/10.1002/jsfa.8628.

16. Meng, X.-H.; Liu, C.; Fan, R.; Zhu, L.-F.; Yang, S.-X.; Zhu, H.-T.; Wang, D.; Yang, C.-R.; Zhang, Y.-J. Antioxidative Flavan-3-ol Dimers from the Leaves of Camellia fangchengensis. J Agric Food Chem 2018, 66, 247-254, https://doi.org/10.1021/acs.jafc.7b04572.

17. Kumar, S.; Pandey, A.K. Chemistry and Biological Activities of Flavonoids: An Overview. The Scientific World Journal 2013, 2013, https://doi.org/10.1155/2013/162750.

18. Wink, M. Modes of Action of Herbal Medicines and Plant Secondary Metabolites. Medicines 2015, 2, 251286, https://doi.org/10.3390/medicines2030251.

19. Li, T.; Li, X.; Dai, T.; Hu, P.; Niu, X.; Liu, C.; Chen, J. Binding mechanism and antioxidant capacity of selected phenolic acid - $\beta$-casein complexes. Food Research International 2020, 129, https://doi.org/10.1016/j.foodres.2019.108802.

20. Santiago Schiaffino, O.; Luisa Carlota López, C.; María Kimatrai, S. In silico pharmacology for a multidisciplinary drug discovery process. Drug Metabolism and Personalized Therapy 2012, 27, 199-207, https://doi.org/10.1515/dmdi-2012-0021.

21. Sayed, A. M.; Khattab, A. R.; AboulMagd, A. M.; Hassan, H. M.; Rateb, M. E.; Zaid, H.; Abdelmohsen, U. R. Nature as a treasure trove of potential anti-SARS-CoV drug leads: a structural/mechanistic rationale. RSC Advances, 2020, 10(34), 19790-19802, https://doi.org/10.1039/d0ra04199h

22. Daina, A.; Michielin, O.; Zoete, V. SwissADME: a free web tool to evaluate pharmacokinetics, drug-likeness and medicinal chemistry friendliness of small molecules. Scientific Reports 2017, 7, https://doi.org/10.1038/srep42717.

23. Wu, R.; Wang, L.; Kuo, H. C. D.; Shannar, A.; Peter, R.; Chou, P. J.; Li, S.; Hudlikar, R.; Liu, X.; Liu, Z.; Poiani, G. J.; Amorosa, L.; Brunetti, L.; Kong, A. N. An Update on Current Therapeutic Drugs Treating COVID-19. Current Pharmacology Reports, 2020. 6(3), 56-70. https://doi.org/10.1007/s40495-020-002167.

24. Trott, O.; Olson, A.J. AutoDock Vina: Improving the speed and accuracy of docking with a new scoring function, efficient optimization, and multithreading. Journal of Computational Chemistry 2010, 31, 455461, https://doi.org/10.1002/jcc.21334.

25. Sayed, A.M.; Khattab, A.R.; AboulMagd, A.M.; Hassan, H.M.; Rateb, M.E.; Zaid, H.; Abdelmohsen, U.R. Nature as a treasure trove of potential anti-SARS-CoV drug leads: a structural/mechanistic rationale. $R S C$ Advances 2020, 10, 19790-19802, https://doi.org/10.1039/D0RA04199H.

26. Ho, T.-Y.; Wu, S.-L.; Chen, J.-C.; Li, C.-C.; Hsiang, C.-Y. Emodin blocks the SARS coronavirus spike protein and angiotensin-converting enzyme 2 interaction. Antiviral Research 2007, 74, 92-101, https://doi.org/10.1016/j.antiviral.2006.04.014.

27. Adedeji, A.O.; Severson, W.; Jonsson, C.; Singh, K.; Weiss, S.R.; Sarafianos, S.G. Novel Inhibitors of Severe Acute Respiratory Syndrome Coronavirus Entry That Act by Three Distinct Mechanisms. $J$ Virol 2013, 87, 8017-8028, https://doi.org/10.1128/JVI.00998-13.

28. Lin, C.-W.; Tsai, F.-J.; Tsai, C.-H.; Lai, C.-C.; Wan, L.; Ho, T.-Y.; Hsieh, C.-C.; Chao, P.-D.L. Anti-SARS coronavirus 3C-like protease effects of Isatis indigotica root and plant-derived phenolic compounds. Antiviral Research 2005, 68, 36-42, https://doi.org/10.1016/j.antiviral.2005.07.002.

29. Zhou, L.; Liu, Y.; Zhang, W.; Wei, P.; Huang, C.; Pei, J.; Yuan, Y.; Lai, L. Isatin Compounds as Noncovalent SARS Coronavirus 3C-like Protease Inhibitors. Journal of Medicinal Chemistry 2006, 49, 3440-3443, https://doi.org/10.1021/jm0602357.

30. Tian, W.; Chen, C.;Liang, J. CASTp 3.0: Computed Atlas of Surface Topography of Proteins and Beyond. Biophysical Journal, 2018, 114(3), 50, https://doi.org/10.1016/j.bpj.2017.11.325

31. Tahir ul Qamar, M.; Alqahtani, S.M.; Alamri, M.A.; Chen, L.-L. Structural basis of SARS-CoV-2 3CLpro and anti-COVID-19 drug discovery from medicinal plants. Journal of Pharmaceutical Analysis 2020, 10, 313-319, https://doi.org/10.1016/j.jpha.2020.03.009.

32. Ryu, Y.B.; Jeong, H.J.; Kim, J.H.; Kim, Y.M.; Park, J.-Y.; Kim, D.; Naguyen, T.T.H.; Park, S.-J.; Chang, J.S.; Park, K.H.; Rho, M.-C.; Lee, W.S. Biflavonoids from Torreya nucifera displaying SARS-CoV 3CLpro inhibition. Bioorganic \& Medicinal Chemistry 2010, 18, 7940-7947, https://doi.org/10.1016/j.bmc.2010.09.035.

33. Elfiky, A.A. Ribavirin, Remdesivir, Sofosbuvir, Galidesivir, and Tenofovir against SARS-CoV-2 RNA dependent RNA polymerase (RdRp): A molecular docking study. Life Sciences 2020, 253, https://doi.org/10.1016/j.lfs.2020.117592.

34. Faruk Khan, M.O.; Deimling, M.J.; Philip, A. Medicinal Chemistry and the Pharmacy Curriculum. American Journal of Pharmaceutical Education 2011, 75, https://doi.org/10.5688/ajpe758161. 
35. Andersson, S.; Antonsson, M.; Elebring, M.; Jansson-Lofmark, R.; Weidolf, L. Drug metabolism and pharmacokinetic strategies for oligonucleotide- and mRNA-based drug development. Drug Discovery Today 2018, 23, 1733-1745, https://doi.org/10.1016/j.drudis.2018.05.030.

36. Thirumalaisamy, R.; Murugan, P.; Srinivasan, P.; Arjunan, S.; Selvankumar, T. Phytochemical 6-Gingerol - A promising Drug of choice for COVID-19. International Journal of Advanced Science and Engineering 2020, 6, 1482-1489, https://doi.org/10.29294/IJASE.6.4.2020.1482-1489. 